\title{
On Eight Grade Students Understanding in Solving Mathematical Problems
}

\author{
Ani Minarni ${ }^{1}$ \\ ${ }^{1}$ Department of Mathematics, Faculty of Mathematics \& Natural Sciences, State University of Medan, Indonesia \\ Correspondence: Ani Minarni. E-mail: animinarni10@gmail.com
}

Received: September 8, 2017

Accepted: October 19, $2017 \quad$ Online Published: November 28, 2017

doi:10.5539/ass.v13n12p86

URL: https://doi.org/10.5539/ass.v13n12p86

\begin{abstract}
Human must have the ability to understand, because understanding can prevent people from misunderstandings and conflicts. Similarly, public junior high school (PJHS) students need to have mathematical understanding ability (MUA) for a reason, that is, MUA is an important part in problem solving. In fact, MUA of PJHS students was still low. This research was conducted to contribute in improving students' MUA. There were 158 students engaged in the experiment classroom as well as in the conventional one taken from PJHS 1, 2, and 4 from district of Deli Serdang, PJHS 17 and 22 from Medan City, Indonesia. Joyful problem based learning (JPBL) approach was applied to attain the purpose of the research. The study used essay-test to measure students' MUA. The score obtained was then analyzed by t-independent test, while student performance in solving MUA problems was described descriptively. Results of the research: (1) Students MUA' score was higher in the experiment classroom than in the conventional one. (2) The improvement of students MUA in the experiment classroom belongs to medium category. (3) The students' performance in MUA was better in the JPBL classroom than it was in the conventional one. Some students faced difficulties both in explaining the solution and in giving example of a mathematical concept. Overall, the students' performance was best at the aspect of presenting problem in mathematics equation. Based on the findings, the study suggests teachers to give reinforcement in both aspect where students lacked of by, for example, encouraging them to solve a variety of problems which eliciting the aspect of explaining and giving examples.
\end{abstract}

Keywords: Mathematical understanding, Mathematical Problem Solving, Joyful Problem Based Learning

\section{Introduction}

Problem solving is an ability or skill very important be acquired, because from birth humans have faced challenging problems that forced him get the solution. The solution that a baby exhibits when he feels thirsty is crying and his mouth moves to find a source of milk. Until we are old, we still face problems, such as the problem of chewing food if the food has a rather hard texture. Problems not only faced by ordinary man, but also experienced by experts in various fields of science and work, and junior school students, certainly.

Assumed that through learning mathematics, the ability of problem solving can be nurtured and grown. This is quite reasonable considering that learning mathematics demands patience, fear, prudence, unyielding spirit, honesty, discipline, consistency, faithfulness and reasoning correctly. Especially when learning mathematics through solving ill-structured problems. Problem solving is the process of applying knowledge in various new and unfamiliar situations (Anderson, et. al., 2001). Mathematical problem solving of course is the process of applying mathematical knowledge into new and unfamiliar mathematical problems.

It can be seen in NCTM (2000) some examples of problem designed to elicit students' problem solving skills, while some other problems have the purpose to elicit the students' reasoning, understanding, representation, communication, and connection skills. In order the students be good at problem solving, they must be qualified in some of these skills, as well as having a good disposition (Kilpatrick, Swafford, \& Findell, 2001). In fact, preliminary research turned out to show an unfavorable result in term of the students' mathematical understanding (Minarni, Napitupulu, \& Husein, 2016). For this reason, researchers develop instruction materials aimed to improve the ability of mathematical understanding of grade 8 junior high school students.

The results showed that the instruction materials are quite effective in improving the students' mathematical understanding ability [MUA]. The students' achievement in MUA test are 62 from the 100 scale. This indicates that the ability of mathematical understanding improved through implementing Joyful Problem-based Learning (JPBL) (Minarni \& Napitupulu, 2017).

In current research, JPBL implemented more widely scope, including 158 students from five schools in District of Deli Serdang and Medan City in the hope that more students will experience improvement in mathematical understanding ability. 


\section{Literature Review}

Observing what is mathematics and how importance the role of mathematics in human life, it is natural that students in schools are required to have the ability to understand mathematics, proficient in various mathematical representations, and problem-solving skills (Depdiknas, 2006). Some of these skills (abilities) are components of mathematical proficiency students must possess (Kilpatrick, Swafford, \& Findell, 2001). Understanding is knowing what and why something is done, being able to do something but not knowing the underlying science (Skemp, 1987), agreeing with the expert, can look at the characteristics of the deeper concept, seek specific information in a situation quickly, be able to represent a situation, and looking at a situation with a mental model (Nickerson, 1985). Students understand when they build a relationship between new knowledge and incoming knowledge with prior knowledge. According to Marzano \& Kendall (2007), students said to understand if new knowledge integrated with existing cognitive structure. Understanding interpreted as the ability to symbolize the knowledge and integration of that knowledge into the cognitive structure already present in a person.

Understanding is the ability to bind relationships between pieces of information, dynamic, changing and developing (Hiebert \& Carpenter, 1992). In addition, understanding is one's ability to construct the meaning of instructional messages including oral, written, and graphical communications of any kind when presented in a classroom, book, or computer screen (Anderson, et al., 2001). The process of understanding is the process of building knowledge networks through reasoning, developing explanations, learning by example, linking with initial knowledge, and engaging in practical activities and intellectual activities (Sierspinska 1994).

Mathematical understanding is a network of representations made and related to mathematical concepts (Barmby, et al., 2007). It means that mathematical understanding is the ability to make the connection between mathematical facts and represent them. When students have mathematical connection and representation ability, then it can be expected the students master the aspects of understanding ability as proposed by Anderson, et al. (2001), they are able to interpreting, modelling, classifying, summarizing, comparing, and explaining. Meanwhile, inferred to Hiebert \& Carpenter (1992), when mental representation of math is part of the representational network, one said understand mathematics. Therefore, the students understand mathematics if they can represent information or math problems in any other form. It is well known that some kind of math representation including mathematical model (mathematical equation), graph, table, sketch (figure, image), various diagram, for example Venn diagram, tree diagram, and others.

Mathematical understanding can be achieved even be improved through constructivism-based learning that requires students to be actively involved in solving mathematical problems (Carpenter \& Lehrer, 1999; NCTM, 2000). Throughout learning process, teachers can assess and improve mathematical understanding, too, among others, through observing the student's faulty in doing math, looking at the relationships students make between symbols, and corresponding symbolic and referential procedures, looking at the relationship between symbolic procedures and informal problem-solving situations, and examine the relationships that are made between different symbolic systems (Hiebert \& Carpenter, 1992). In addition, Pirie \& Kieren (1994) proposed how to characterize the growth or mathematical understanding and how to represent it.

One of learning based constructivism is Problem-based learning (PBL) (Arends, 2004). Minarni (2013) described how PBL influence students' mathematical understanding, while Napitupulu, Suryadi, \& Kusumah (2016) showed how PBL cultivated mathematical reasoning ability of upper secondary students. Meanwhile, joyful learning suggested by Puri (2014) is meaningful to integrate into PBL, so we call our developed learning approach as Joyful Problem-based Learning (JPBL). JPBL has proven effective in improving mathematical understanding (Minarni, Napitupulu, \& Husein, 2016) and representation ability of 88 students distributed in Tebing Tinggi, Pematangsiantar City and Medan City (Minarni \& Napitupulu, 2017).

\section{Research Questions}

The questions of the research are:

(1) Whether MUA' Score of the students is higher in experiment class than it is in conventional one.

(2) Whether the improvement of students' MUA in experiment class high enough.

(3) How is the performance of the students in solving mathematical understanding problems? In which aspect of MUA the students faced difficulties and in which aspect they have mastered.

\section{Research Method}

Type of the research is experimental since this is the dissemination phase of our developmental research. The experiment conducted along April to June 2017. The population is public junior high school (PJHS) students in North Sumatera, Indonesia. There are 158 students from PJHS 1, 2, and PJHS 4 in District Deli Serdang, PJHS 17 and PJHS 22 in Medan City, included as samples.

The experimental class uses instruction materials based-on Joyful Problem-based Learning (JPBL), consisting teacher-guided book, students' math book and Students Activity Sheets (SAS). JPBL approach implemented in the experiment classroom. While, direct instruction as Conventional learning approach implemented in the conventional classroom. Topics that students studied are linear equation of two variables and Pythagorean rules which packed in Student Activity Sheet (SAS). 
There are nine SAS given along all learning sequence. All students administered MUA test at the end of learning program. The students in JPBL classroom also take pre-test since we not only want to measure the difference of MUA achievement between the students in JPBL classroom and they are in conventional classroom but also interested in the improvement of students' MUA in JPBL classroom. The MUA test used is five items essay test with 70 minutes available time. The test was designed based on MUA aspects that modify from NCTM (2000), Anderson, et.al. (2001), and 2013-Curriculum (Depdikbud, 2013):

1. Create mathematical equation to solve the problem.

2. Propose an example and non-example of math concept.

3. Classify mathematical equation into proper group.

4. Create graph as an interpretation of the problem and explain the solution obtained.

5. Using similarity (analogy) to solve problems.

Three of essay post-test were presented in Appendix 1.

At the time of topic related to linear equation of two variables, learning process took place at mini bookstore and canteen in the school area so that the students learned to realize the real problem, were interested in mathematics and motivated to solve the problems at hands. Whenever the topic related to Pythagorean rule, they searched for triangle-shaped around the school. In this activity, teacher act as a couch.

As well as observation towards students' activity in solving problems and teacher activity in implementing JPBL, interview also conducted to both of them in order to enrich finding in qualitative data. Along with students' performance, both the students' difficulties and fluency in solving MUA problems are investigated through students' answer sheets. Scoring rubric of MUA test included in Appendix 2, while an example of Students Activity Sheets (SAS) presented in Appendix 3.

Score of MUA test analyze by t-Independent test, while result of observation and interview analyze descriptively.

\section{Results And Discusion}

\subsection{The Students' Score in MUA Test}

Result of mathematical understanding ability (MUA) test both in JPBL and in Conventional class is presented in Table 1.

Table 1. Average Score of MUA Post-test

\begin{tabular}{ccccc}
\hline Approach & $\mathrm{N}$ & Mean & Std. Deviation & Std. Error Mean \\
\hline JPBL & 158 & 12.66 & 2.271 & .181 \\
Conventional & 158 & 7.00 & 1.184 & .094 \\
\hline
\end{tabular}

Note: Ideal score $=20$

Table 1 shows that MUA score of the students in experiment (JPBL) class is higher than it is in conventional class. Result of t-independent test, presented in Appendix 4, shows that there is significant difference of MUA average score between the two classes. By referring to Table 2, the students' MUA achievement in the JPBL class is better than it is in conventional class. According to Glass \& Hopkins (1996), it means treatment (JPBL) gives significant effect towards students' MUA. Standard deviation of the MUA scores is homogeny, meaning that there is no students get MUA scores far above average, whereas no student get scores far below average. The lowest score is 8 and the highest score is 17, just around the average score. Average score of MUA post-test at each school presented in Table 2.

Table 2. Average Score of MUA Post-test at Each School

\begin{tabular}{cccccc}
\hline School & Class & Average & SD & Sample size & Total \\
\hline \multirow{2}{*}{ PJHS 1 } & Conventional & 7.531 & 1.199 & 32 & 64 \\
& JPBL & 12.531 & 1.871 & 32 & 62 \\
PJHS 2 & Conventional & 7.290 & 0.923 & 31 & \\
& JPBL & 12.452 & 2.353 & 31 & 40 \\
PJHS 4 & Conventional & 7.250 & 0.994 & 20 & 70 \\
& JPBL & 12.550 & 1.562 & 20 & 35 \\
PJHS 17 & Conventional & 6.249 & 1.249 & 35 & \\
& JPBL & 12.771 & 2.587 & 30 & 316 \\
\hline
\end{tabular}

Note: Ideal score $=20$

Table 2 shows that at every school, MUA average score of the students in JPBL class is also higher than it is in conventional one. Even though, some students still get low scores. Output of statistic test give significant result for these differences. 


\subsection{The Improvement of Mathematical Understanding Ability}

The improvement of the students' MUA in the JPBL class calculated using Hake normalized gain index or N-gain, and presented in Table 3.

Table 3. N-gain of Students' MUA in JPBL Classroom

\begin{tabular}{ccccc}
\hline MUA Test & $\mathrm{n}$ & Mean & Std. Deviation & N-gain \\
\hline Pre & 158 & 7.00 & 1.184 & 0.283 \\
Post & 158 & 12.66 & 2.271 & \\
\hline
\end{tabular}

Note: Ideal score $=20$

According to Hake (1998), this gain belongs to medium category. Required implementation of constructivism-based learning more often, especially JPBL, so that problem-solving activities become a culture among PJHS students. Even, children should be encouraged early to involve in solving simple problems. Because in fact, since the baby, human being have confronted with the problem.

\subsection{The Students' Performance in Solving MUA Problems}

Result of MUA post-test classify into tree category as presented in Table 4. The classification pointed out the performance category of students' performance in MUA test.

Table 4. The MUA Performance of the Students in JPBL classroom

\begin{tabular}{ccc}
\hline Criteria & Performance & N \\
\hline MUA $<10.4$ & Low & 33 \\
$10.4 \leq$ MUA $<14.9$ & Mediocre & 88 \\
MUA $\geq 14.9$ & High & 37 \\
\hline Total & - & 158 \\
\hline
\end{tabular}

Note: Mediocre category: MUA $\leq|\mu \pm \sigma| ; \mu=12.66 ; \sigma=2.271$

Based on Table 4, there are 88 of 158 students belongs to mediocre category, 37 belongs to high category, and 33 of them $(<21 \%)$ belongs to low category. This is quite good, because understanding is a high-level thinking element well above the retrieval (Anderson, et. al., 2001; Marzano \& Kendall, 2007; Minarni, Napitupulu, \& Husein, 2016). Taxonomy of educational objective stated that retrieval is a product of memorization, while understanding skills is a product of connection, representation also reasoning. Someone use reasoning to connect one piece of information to others. Furthermore, students' performance can still improve because the age of students is in the phase of rapid cognitive development and basically all human being have capacity to learn in a rapid rate whenever he/she want it. Thus, mathematical understanding of the students is still developed. One other factor besides learning approach that give influence to the students' thinking development is the teacher belief. The teachers should believe their students are outstanding, and then they will be outstanding.

Joyful Problem-based learning make positive emotion since the students enjoy along learning activity, so that enable knowledge store in long term memory for long period and make it easier to apply in new and unfamiliar situations or problems. JPBL make the students fully engage in learning. Average number of students' engagement in learning activity attains more than $85 \%$.

\subsection{The Students Difficulty and Fluency in Solving MUA Problems}

Investigation towards students' difficulty is important because it means the students could not answer the question or give wrong solution. According to Hiebert \& Carpenter (1992), wrong solution or faulty the students proposed is one of a few way to improve mathematical understanding. In this part, the discussion and suggestion directed to the difficulties the students faced in solving MUA problems by referring to Statistic of Students' Post-test Result in Each Aspect of MUA presented in Appendix 5, and students' answer sheet. Along with the students' difficulties, we also observed the fluency they achieved in solving the problems. For these purpose, some examples of students answer sheet presented below.

\section{a. PJHS 1}

We can found in Appendix 5 that the students at PJHS 1 face difficulties in the $2^{\text {nd }}$ and $4^{\text {th }}$ aspects of MUA. The $2^{\text {nd }}$ aspect is to propose example of gradient concept. The $4^{\text {th }}$ aspect is to draw graph in order to aid him/her solve the problem and explain the solution obtained. An example of student' answer sheet showed his/her difficulty in $2^{\text {nd }}$ aspect of MUA attached in Figure 1.

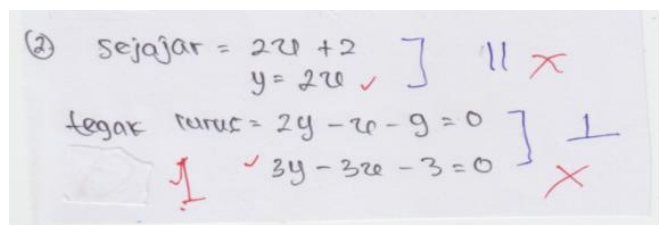

Figure 1. Student' Difficulty in $2^{\text {nd }}$ Aspect of MUA 
If the student in Figure 1 write $y=2 x+2$ instead of $2 x+2$, then it is true as an example of two parallel line. On the other side, example of line perpendicular to other line she/he proposed is wrong. It means, she/he has not understand line concept and the nature of gradient yet. Even, this shows he/she has difficulty in the process of retrieval knowledge from his/her cognitive structure. Therefore, the teacher should give more attention to this aspects by giving frequent problems elicited the ability of giving examples as well as non-example. We can found examples of such problems in NCTM (2000) as well as in many published scientific articles.

The students have fluent in the $1^{\text {st }}$ and $3^{\text {rd }}$ aspect of MUA, that is to create mathematical equation, and classify mathematical equation into proper group. Figure 2 clarifies the student fluency in $1^{\text {st }}$ aspect of MUA.

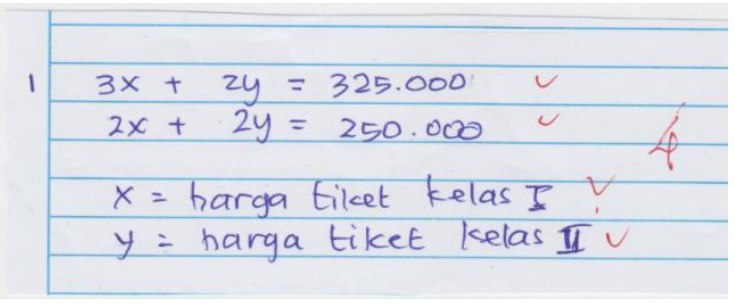

Figure 2. Student' Fluency in $1^{\text {st }}$ Aspect of MUA

In Figure 2, the student create both correct mathematical equation for the problem and give correct explanation about each variable included in the equation. This student can represent real life problem in mathematical symbol. In other word, he has capable in making relationship between real life problem and math symbol. This capability is an aspect of mathematical understanding, as stated by Carpenter \& Lehrer (1999). Overall, most of the students has capable in complete this task, a few number of them still enable.

\section{b. PJHS 2}

The difficulties of the students at PJHS 2 in solving MUA test are in the $4^{\text {th }}$ and $5^{\text {th }}$ MUA aspects. The $4^{\text {th }}$ aspect is to draw graph in order to aid him/her solve the problem and explain the solution obtained, and $5^{\text {th }}$ aspect is to use similarity (analogy) to solve the problem. Figure 3 expresses the work of the students experienced difficulty in the $4^{\text {th }}$ aspect of the MUA.

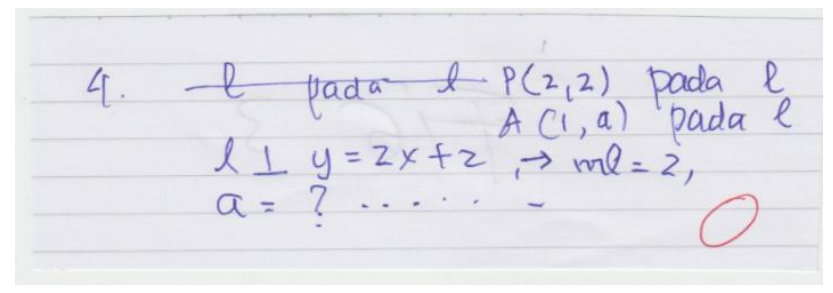

Figure 3. Student' Difficulty in $4^{\text {th }}$ aspect of MUA

Researching students' performance in solving problems aimed at exposing students' abilities in the $4^{\text {th }}$ aspect of the MUA, it appears that this student having difficulty. This student could not create a graph as requested. If he/she represent information in a graph, probably he/she would be easier to get a solution. One of the striking things about the observation results is that students avoid the activities of drawing to represent the problem. If confirmed to the interview results, this issue indicate that the students are not used to drawing, so rigidly when forced to make drawings/sketches on a situation or problem. While, it is clear that drawings or sketches are helpful to make problem clear and help to avoid misconceptions. Sketches/drawings/figure is useful representation. As implied from Carpenter \& Lehrer (1999), representation is an element of understanding. Therefore, if one lack of mathematical representation then he/she could not acquires mathematical understanding.

The students at this school fluent in the $2^{\text {nd }}$ and $3^{\text {rd }}$ aspect of MUA, they are to create mathematical equation, and classify mathematical equation into proper group, such as linear equation of one variable, linear equation of two variables, or system of linear equation of two variables. One of the student' work showing fluency in $3^{\text {nd }}$ aspect of MUA depicted in Figure 4.

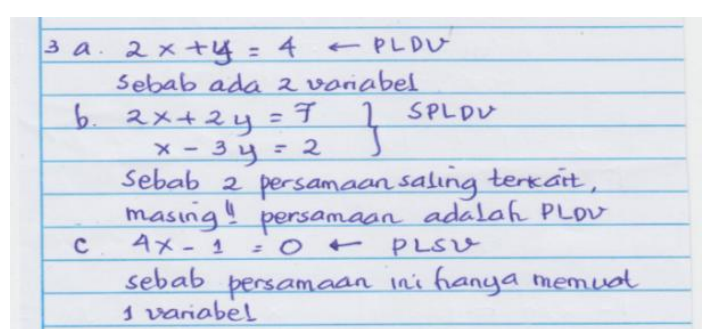

Figure 4. Student' Fluency in $3^{\text {rd }}$ aspect of MUA 
The performance of the student depicted in Figure 4 showed that he/she is fluent in solving MUA problem related to $3^{\text {rd }}$ aspect of MUA. That is, he/she fully understands the concept of linear equations. Moreover, he/she is able to classify the types of linear equations to linear equation of one variable, linear equation of two random variable, and the system of linear equation of two variable, and give explanation. According to Marzano \& Kendall (2007), this student has the ability to symbolize knowledge and integrate it into the knowledge already available in his cognitive structure. Explanation given by this student showing the characteristic of understanding (Sierspinska, 1994). Not many students can complete such MUA task.

\section{c. PJHS 4}

The students at PJHS 4 face difficulties in the $4^{\text {th }}$ and $5^{\text {th }}$ aspects of MUA. The $4^{\text {th }}$ aspect is to draw graph in order to aid him/her solve the problem and explain the solution obtained, and $5^{\text {th }}$ aspect is to use similarity (analogy) to solve the problem. Figure 5 depicted student' difficulty in completing $5^{\text {th }}$ aspect of MUA.

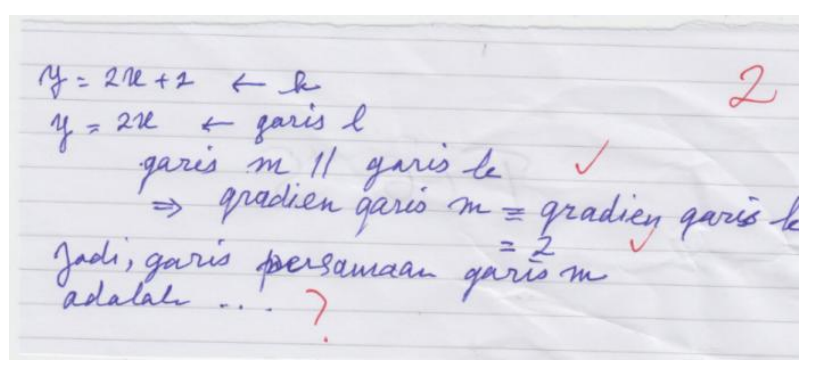

Figure 5. Student' Difficulty in $5^{\text {th }}$ aspect of MUA

The student performance shown in Table 5 point out that he/she understands the gradient concept of a line, but does not yet understand the concept of two parallel lines. That is why after determine gradient of line, he/she stopped, could not complete this task anymore. When compared with observations, this student is inconsistently involved in discussions or solving problems with his friends in groups. Thus, it is hard for him to grasp full understanding in math topic learned.

The students at this school have mastered in the $2^{\text {nd }}$ and $3^{\text {rd }}$ aspect of MUA, that is to create mathematical equation, and classify mathematical equation into proper group. We give an example of student' performance in completing $2^{\text {nd }}$ aspect of MUA task as presented in Figure 6.

2 a $y_{1}=m \times \quad \| \quad y_{2}=m x-1$
sebal gradien $y_{1}$ dan $y_{2}$ sama.
b. $y_{1} \perp y_{2}$ jika gradien $y_{1}=$ gradien $y$
m $m_{y_{1}} \neq m_{y_{2}}=-1$
my $=2 \Rightarrow m y_{2}=-\frac{1}{2}$
Jadi, $y_{1}=2 \times \perp y_{2}=-\frac{1}{2} \times$

Figure 6. Student' Fluency in $2^{\text {nd }}$ aspect of MUA

Performance of the student displayed in Figure 6 shows that he/she is fluent in giving an example of two parallel lines along with correct explanation as well as proposing example of two perpendicular lines. Observation results revealed that this student actively engage in group discussion to solve the problem, even, sometimes dominate the group.

\section{d. PJHS 17}

The second and $4^{\text {th }}$ aspect of MUA are the difficulties aspects for the students at PJHS 17. Second aspect is to propose an example of gradient concept, and $4^{\text {th }}$ aspect is to draw graph in order to aid him/her solve the problem and explain the solution obtained. Figure 7 shows the student' difficulty in solving $2^{\text {nd }}$ aspect of MUA problem.

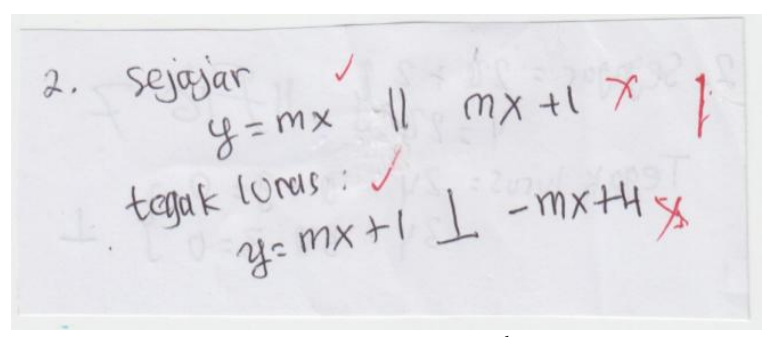

Figure 7. Student' Difficulty in $2^{\text {nd }}$ aspect of MUA

The solution proposed by the student, almost correct. However, he/she did not write $y=m x+1$ parallel to $y=m x$ 
instead of $m x+1$ parallel to $y=m x$. Result of interview to this student find out that in his mind ' $m x+1$ ' is an equation, a line. The purpose is to avoid the repetition of writing the letter $y$. There is obstacle to declaring what he thinks in his mind. This shows that the concept of line equation has not been firmly entrenched in the cognitive structure of this student so it is not easy for him to retrieve that concept. According to Marzano \& Kendall (2007), of course the process of retrieval knowledge is to use in problem solving.

The students at PJHS 17 fluent in the $1^{\text {st }}$ and $3^{\text {rd }}$ aspect of MUA, that is to create mathematical equation, and classify mathematical equation into proper group. Figure 8 clarifies that statement.

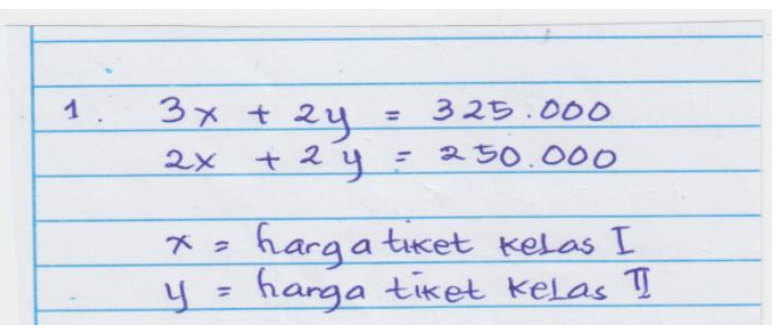

Figure 8. Student' Fluency in $1^{\text {st }}$ aspect of MUA

Figure 8 shows that the student has the capability in creating mathematical equation and explaining the meaning of each variable included in the equation. Creating math equation for a problem is one kind of interpreting ability that is important aspect of MUA as stated by Anderson, et. al. (2001). Based on data in Appendix 5, the students at all school included in the research have fluent in this aspect of MUA.

e. PJHS 22

The students at PJHS 22 face difficulties in the $2^{\text {nd }}$ and $4^{\text {th }}$ of MUA aspects. The $4^{\text {th }}$ aspect is to draw graph in order to aid him/her solve the problem and explain the solution obtained. Like the students at PJHS 2, the students at this school also do not like to make pictures. They always shy away from the task of making pictures. In drawing art lessons, Indonesian students generally only know to make two mountains flanking the sun that shines. It is rare that once a student stands out in the art of drawing.

The $2^{\text {nd }}$ aspect is to explain the solution. Example of student difficulty in completing second aspect of MUA presented in Figure 9.

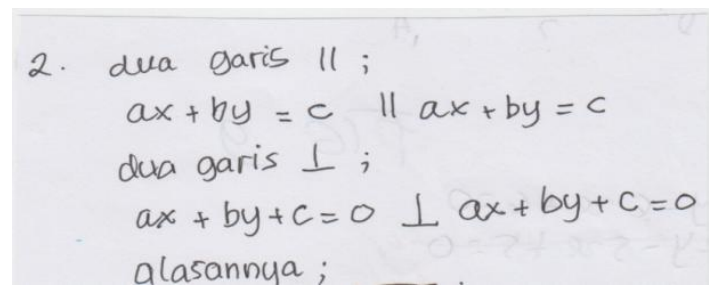

Figure 9. Student' Difficulty in $2^{\text {nd }}$ aspect of MUA

What the student presented in Figure 9 shows that he/she know line equation as $\mathrm{a} x+\mathrm{b} y=0$ and $\mathrm{a} x+\mathrm{b} y+\mathrm{c}=0$. He/she wrote $\mathrm{a} x+\mathrm{b} y+\mathrm{c}=0$ perpendicular to $\mathrm{a} x+\mathrm{b} y+\mathrm{c}=0$. In this case, he/she has not understand the concept of two lines perpendicular to each other yet. Obviously, many of students included in the research need more practice to acquire the concept of parallel as well as perpendicular line.

The students at PJHS 22 fluent in the $1^{\text {st }}$ and $3^{\text {rd }}$ aspect of MUA, that is to create mathematical equation, and classify mathematical equation into proper group, such as linear equation of one variable, linear equation of two variables, or system of linear equation of two variables. Figure 10 clarifies the student' fluency in completing $3^{\text {rd }}$ aspect of MUA.

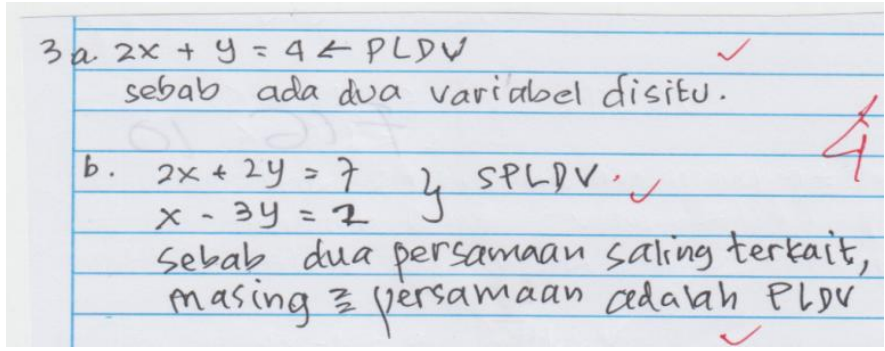

Figure 10. Student' Fluency in $3^{\text {rd }}$ aspect of MUA

It can be seen in Figure 10 that this student understand enough what is linear equation of one variable, linear equation of two variables, and system of linear equation of two variables. In addition, he/she give true explanation for each 
claimed he/she made.

Finally yet importantly, comparing to TIMMS (Mullis \& Martin, 2012) and PISA (2012) report, MUA score of the students in District Deli Serdang and Medan City are quite good. Reported by Mullis \& Martin, Indonesian students' score for problem solving is categorize low. While the results in this research, students achieve more than $62 \%$ even though the problems more complicated than PISA's or TIMMS'. The rational for this is that students who take the test organized by TIMSS are students who learn through Conventional learning, while those who follow the test in this study are students who learn through joyful problem-based learning. Again, it indicated that joyful PBL is powerful in promoting students' mathematical problem solving. In this case, mathematical problem solving that emphasizes the capability to understand the problem and solve it.

In this study, JPBL gives significant impact doe to the teacher is obedient in implementing JPBL and consistently used the syntax of JPBL. Furthermore, learning process took place not only in the classroom but also in the school garden and at mini bookstore in the school area. The teachers also always start learning activity by raising questions that arouse students' curiosity and motivated them to engage in group-discussion, and provided proportional scaffolding. Nevertheless, it seems that scaffolding is not sufficient if given in front of the class for all students. Scaffolding provided to group discussion, not to all of the students in the classroom because each group had different type of difficulties. However, if it done, the teacher's time and energy is not enough, even for a class of 20 students, around 5 groups. Thus, constructivism-based learning seems to be more powerful if implemented in classrooms with less than 20 students. Of course, it needs forward research to prove this prediction.

\section{Conclusion}

The research results are:

(1) The average score of mathematical understanding test of the students in experiment classroom is higher than it is in Conventional class. It means, the achievement of students' MUA is better in JPBL class than it is in Conventional one.

(2) The improvement of students' mathematical understanding ability in JPBL classroom belongs to medium category.

(3) The students' performance in solving mathematical understanding problems is better in JPBL class than it is in Conventional one. The students faced difficulties both at the aspect of explaining the solution and giving examples of math concept. They do best at the aspect of creating mathematical equation.

\section{References}

Arends, R. I. (2004). Learning to Teach, $6^{\text {th }}$ Ed. Boston: McGraw Hill.

Anderson, L.W. et al. (2001). A Taxonomy for Learning, Teaching, and Assessing. New York: Addison Wesley Longman, Inc.

Barmby, P. et al. (2007). How Can We Assess Mathematical Undestanding. In J. H. Woo, H. C. Lew, K. S. Park, \& D. Y. Seo (Eds.). Proceedings of the 31st Conference of the International Group for the Psychology of Mathematics Education, Vol. 2, pp. 41-48. Seoul: PME.

Carpenter, T. P., \& Lehrer, R. (1999). Teaching and Learning Mathematics with Understanding. In Fennema, E. \& Romberg, T.A. (Eds). Mathematics Classrooms that Promote Understanding. Mahwah: Lawrence Erlbaum Associates, Inc.

Departemen Pendidikan Nasional (2006). Permendiknas No. 22. Jakarta: Depdiknas.

Departemen Pendidikan dan Kebudayaan (2013). Kurikulum 2013: Jakarta: Depdikbud.

Glass, G. V. \& Hopkins, K. D. (1996). Statistical Methods in Education and Psychology, $3^{\text {rd }}$ Ed. Needham Height, MA: A Simon \& Schuster Company.

Hake, R. R. (1998). Interactive-Engagement versus Traditional Methods: A Six-Thousand-Student Survey of Mechanics Test Data for Introductory Physics Courses. Am. J. Phys., 66(1), P.65. http://dx.doi.org/ 10.1119/1.18809

Hiebert, J. \& Carpenter, T.P. (1992). Learning and Teaching with Understanding. In Grouws, D. A. (Ed). Handbook of research on mathematics teaching and learning: A project of the National Council of Teachers of Mathematics. (pp. 65-97). New York, NY, England: Macmillan Publishing Co, Inc.

Kilpatrick, J., Swafford, J., \& Findell, B. (Eds.). (2001). Adding it up: Helping children learn mathematics. Washington, DC: National Academy Press.

Marzano, R.J. \& Kendall, J.S. (2007). The New Taxonomy of Educational Objectives. Thousand Oaks: Corwin Press

Minarni (2013). Pengaruh Pembelajaran Berbasis Masalah (PBL) terhadap Kemampuan Pemahaman dan Pemecahan Masalah Matematis, serta Keterampilan Sosial Siswa SMP. Bandung: Indonesia University of Education (UPI). Unpublished Dissertation.

Minarni, A., Napitupulu, E.E., \& Husein, R. (2016). Mathematical Understanding and Representation Ability of Public Junior High School in North Sumatera. Indo-MS Journal on Mathematics Education, 7(1), 43-56. DOI: 10.22342/jme.7.1.2816.43-56 License: CC BY-NC-ND 4.0. 
Minarni, A. \& Napitupulu, E. E. (2017). Developing Instruction Materials based on Joyful PBL to Improve Students' Mathematical Representation Ability. International Education Studies, 10(9). https://doi.org/10.5539/ies.v10n9p23

Mullis, I.V.S. \& Martin, M.O. (2012). TIMSS in Perspective: Lessons Learned from IEA's Four Decades of International Mathematics Assessment. TIMSS \& PIRLS International Study Center Lynch School of Education, Boston College.

Napitupulu. E.E., Suryadi, D., \& Kusumah, Y.S. (2016). Cultivating Upper Secondary Students' Mathematical Reasoning Ability and Attitudes towards Mathematics through Problem-Based Learning. Indo-MS Journal on Mathematics Education, Vol. 7. No. 2, pp 61-71. DOI: 10.22342/jme.7.2.3542.117-128 • License: CC BY-NC-ND 4.0 .

NCTM (2000). Principle and Standards for School Mathematics. Reston, VA: NCTM.

Nickerson, R. S. (1985). Understanding Understanding. American Journal of Education, 93(2), pp. $201-239$. https://doi.org/10.1086/443791

Pirie, S. \& Kieren, T. (1994). Growth in mathematical understanding: How can we characterize it and how can we represent it? Educational Studies in Mathematics, 26(2), 165-190. https://doi.org/10.1007/BF01273662

PISA (2012). Assessment and Analytical Framework: Mathematics, Reading, Science, Problem Solving, and Financial Literacy, OECD Publishing.

Puri, A. (2014). How to Create Joyful Learning in the Classroom. Available online: www.howtolearn.com.

Sierpinska, A. (1994). Understanding in Mathematics. London: The Falmer Press.

Skemp, R. (1976). Relational Understanding and Instrumental Understanding. Mathematics Teaching, 77, $20-26$.

\section{Appendix 1: Post-test Problems}

1. For the $26^{\text {th }}$ SEA Games soccer tournament in 2011 that took place in Palembang City, the committee provided tickets for Class I and Class II. Mr. $X$ bought three Class I and two Class II for a total of 325,000 rupiahs. If you buy two pieces of class I and two pieces of class II, then you have to pay 250.000 rupiahs. Change the sentences above into algebraic form. Explain the meaning of each variable.

2. Write down two equations of parallel lines and two equations of perpendicular. Explain your answer.

3. Determine the following either a linear equation of one variable, or two variables, or a system of linear equation of two variables. Give explanation to each of your answer.

$$
\begin{array}{ll}
\text { a. } 2 x-y=4 & \text { b. }\left\{\begin{array}{c}
x+2 y=7 \\
x-3 y=2
\end{array} \quad \text { c. } 4 x-1=0\right.
\end{array}
$$

\section{Appendix 2: Scoring Rubric}

Holistic Analytic Marking Scheme for Math Understanding Test

\begin{tabular}{l}
\hline Student performance \\
\hline a. Understand the problem by represent it in sketch (image), graph, diagram, or table that can aid to solve the \\
problem. \\
b. Knowing relevant concept to apply in solving problem \\
c. Showing an aspect of mathematical understanding which is fit to the problem \\
c. Complete operations that lead the correct answer.
\end{tabular}

a. Understand the problem by represent it in the form that can aid to a correct answer if followed by an attempt to solve it.

b. Showing an aspect of mathematical understanding which is fit to the problem

c. The solution included all of mathematical component in the problem

d. Complete operation but not lead to the correct answer

a. Understanding the problem by represent it in the form (sketch, graph, diagram, or table) that can aid to solve the problem.

b. Showing an aspect of mathematical understanding which is fit to the problem

c. The solution not included all of mathematical component in the problem

d. Incorrect answer due to computational error or error in writing mathematical component

a. Understand the problem by represent it in the form that lead to correct answer.

b. Use incorrect concepts or procedures that lead to incorrect answer

1

No answer at all or only rewrite the problem 


\section{Appendix 3: Example of Problems in Student Activity Sheet (SAS)}
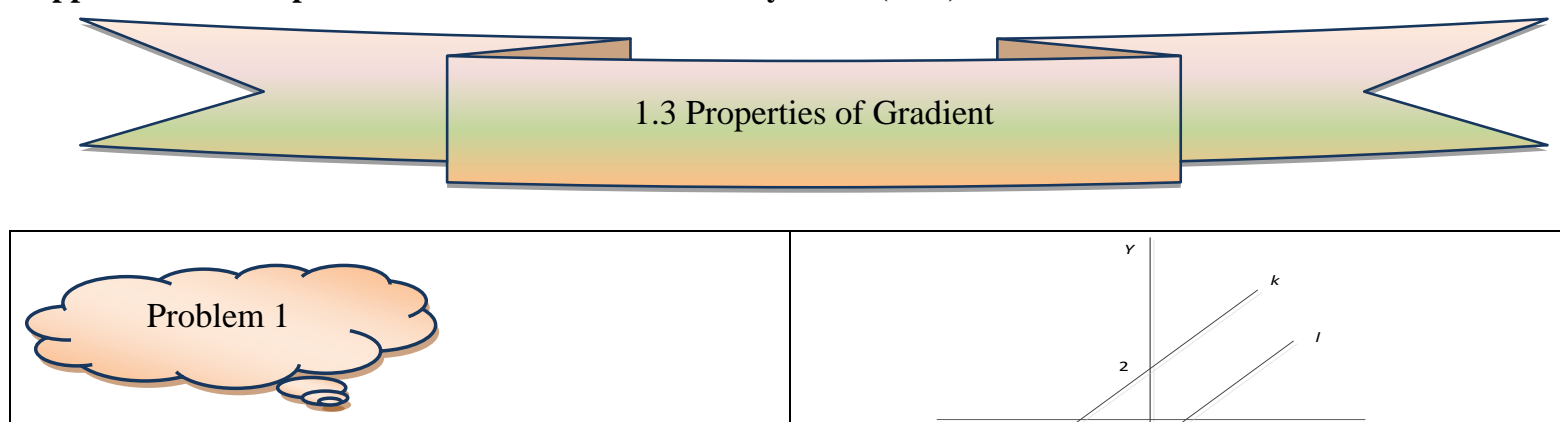

Two roads in a City are in parallel position. The first street and the second street restricted by the row flower garden. Suppose the two road considered as two line that presented in Cartesian coordinate as line $k$ and line $l$ (see Figure 1). Find gradient of line $k$ and the line $l$.

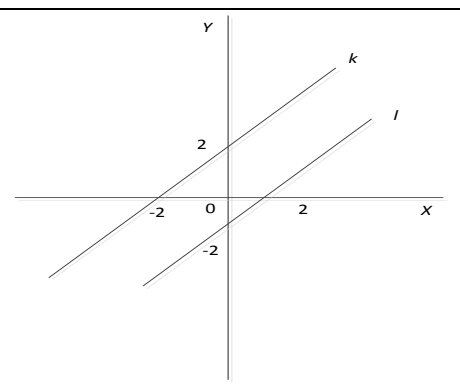

Figure 1
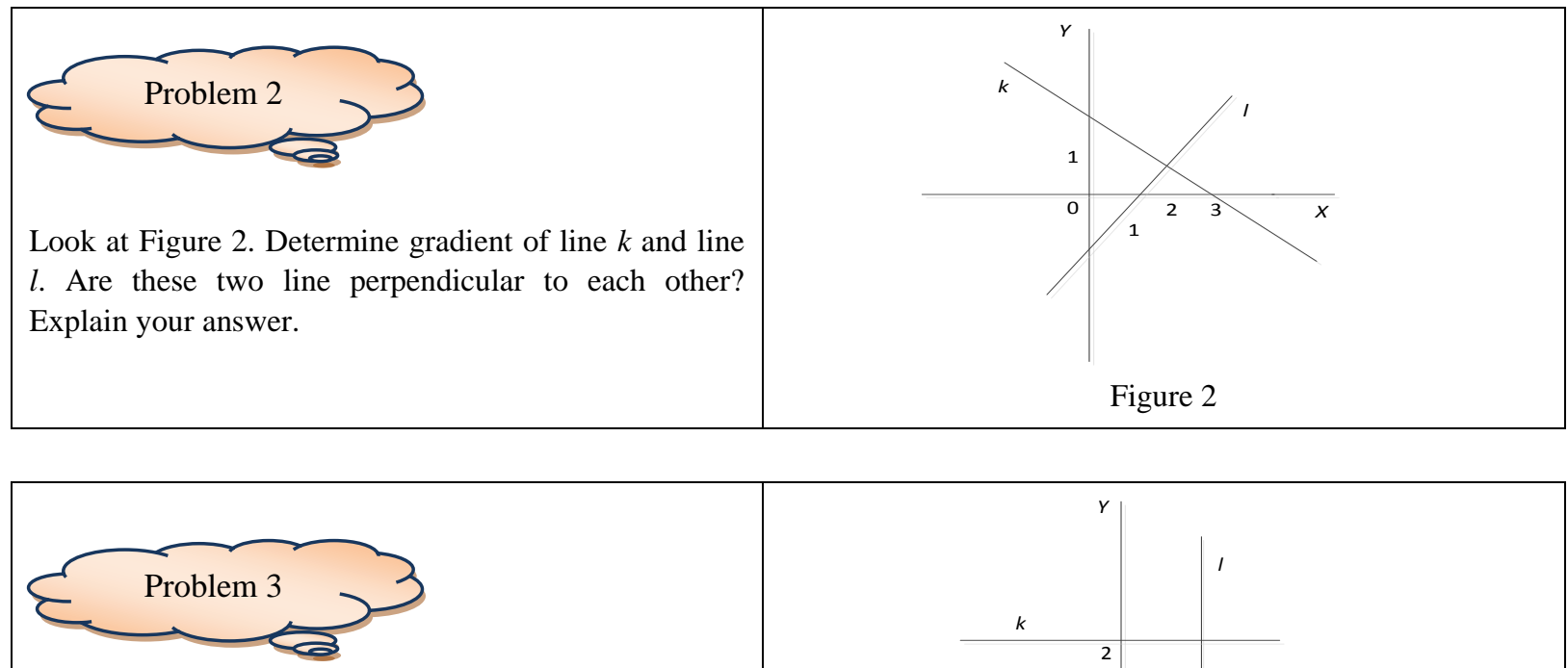

Determine gradient of line $k$ and $l$ on Figure 3.

a. Can you see the relationship between gradient of line $k$ and ordinate- $X$ ?

b. State your opinion about that relationship.

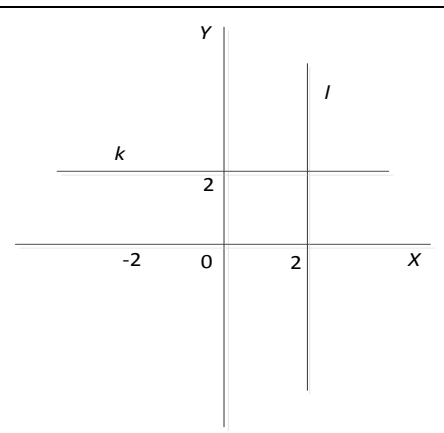

Figure 3

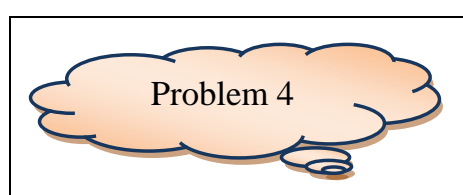

Please, put your attention to Figure 4. Let the equation of line $k$ be $y=-x$ and the equation of line $l$ is $y=x+1$. Determine the coordinates of point $\mathrm{P}$.

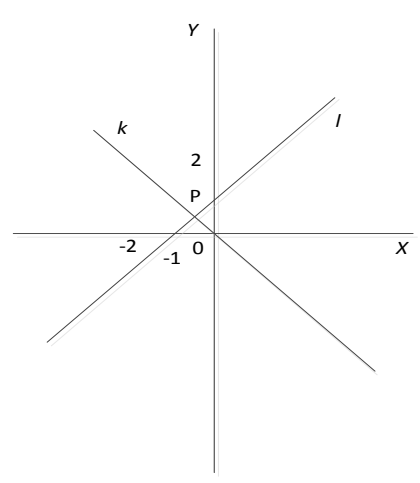

Figure 4 


\section{Conclusion}

1. Gradient of two parallel line is.

2. The product of two gradient of two perpendicular line is.

3. Gradient of a line parallel to abscissa- $X$ is.

4. Gradient of a line parallel to ordinate- $\mathrm{Y}$ is

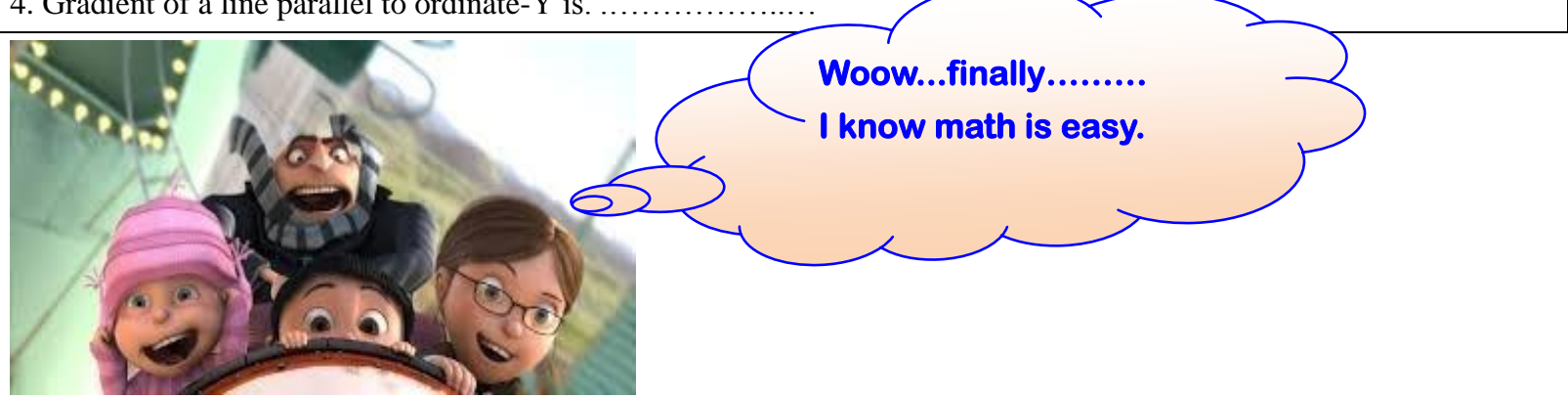

\section{Appendix 4:}

Output of t-Independent test for Equality of Means

\begin{tabular}{ccccccc}
\hline MUA & Sig. & $\mathrm{t}$ & $\mathrm{df}$ & Sig. (2-tailed) & Mean Difference & Std. Error Difference \\
\hline Equal variances assumed & .000 & 27.774 & 314 & .000 & 5.658 & .204 \\
Equal variances not assumed & & 27.774 & 236.463 & .000 & 5.658 & .204 \\
\hline
\end{tabular}

\section{Appendix 5:}

Statistic of Students' Post-test Result in JPBL Class at each Aspect of MUA

\begin{tabular}{|c|c|c|c|c|}
\hline School & $\mathrm{n}$ & Aspect of MUA & Average & SD \\
\hline \multirow[t]{5}{*}{ PJHS 1} & 32 & & 3.00 & 0.75 \\
\hline & & & 1.97 & 0.769 \\
\hline & & & 3.03 & 0.68 \\
\hline & & & 1.78 & 0.69 \\
\hline & & & 2.75 & 0.93 \\
\hline \multirow[t]{5}{*}{ PJHS 2} & 32 & 1 & 2.74 & 0.91 \\
\hline & & 2 & 2.77 & 0.94 \\
\hline & & 3 & 2.96 & 0.82 \\
\hline & & 4 & 2.00 & 0.56 \\
\hline & & 5 & 1.80 & 0.69 \\
\hline \multirow[t]{5}{*}{ PJHS 4} & 20 & 1 & 3.05 & 0.66 \\
\hline & & 2 & 3.20 & 0.67 \\
\hline & & 3 & 3.20 & 0.74 \\
\hline & & 4 & 1.55 & 0.66 \\
\hline & & 5 & 1.50 & 0.59 \\
\hline \multirow[t]{5}{*}{ PJHS 17} & 35 & 1 & 2.91 & 0.73 \\
\hline & & 2 & 1.77 & 1.01 \\
\hline & & 3 & 3.14 & 0.72 \\
\hline & & 4 & 2.08 & 0.80 \\
\hline & & 5 & 2.85 & 1.14 \\
\hline \multirow[t]{5}{*}{ PJHS 22} & 40 & 1 & 3.20 & 0.84 \\
\hline & & 2 & 2.05 & 0.97 \\
\hline & & 3 & 3.05 & 0.73 \\
\hline & & 4 & 2.22 & 0.79 \\
\hline & & 5 & 2.37 & 0.99 \\
\hline Total & 158 & - & - & - \\
\hline
\end{tabular}

\section{Copyrights}

Copyright for this article is retained by the author(s), with first publication rights granted to the journal.

This is an open-access article distributed under the terms and conditions of the Creative Commons Attribution license (http://creativecommons.org/licenses/by/4.0/). 